\title{
REVIEWING LAND ACCESS LIVELIHOOD DIVERSIFICATION STRATEGIES AND FACTORS INFLUENCING WELLBEING OF RURAL HOUSEHOLDS IN MNQUMA, EASTERN CAPE: IMPLICATIONS TO EXTENSION AGENTS
}

\author{
Christian, $\mathbf{M}^{1}$, Luvhengo, $\mathbf{U}^{2}$, Khobai, $\mathbf{H}^{3}$ \& Agbugba, I. K. ${ }^{4}$ \\ Correspondence author: M. Christian. Email: mzuyanda1990@gmail.com
}

\section{ABSTRACT}

The aim of this paper is to analyse the impact of land access and livelihood strategies of rural households to well-being of households' implications to extension agents in Mnquma, Eastern Cape. A cross-sectional research design was utilised to collect data from 105 randomly selected households. Descriptive statistics was then used to profile livelihood strategies and characteristics such as age, gender, years of farm experience, the availability of water and land for crop production and the income farmers generate from the sale of crops produced. Multinomial logistic regression results demonstrated that land size and location have a positive significant influence $(p=0.001)$ on household well-being. It is concluded that though land size has a positive influence on well-being, expanding farms through adding plots and distant farming hinders the attainment of well-being. Moreover, households with large number of dependents and those working in exclusive farming are disadvantaged in the attainment of well-being. There is therefore room to enhance progress in attainment of well-being through reducing the distance to farms and promoting diversification of livelihood strategies. The Eastern Cape department of Agriculture and Rural Development is advised to support distant farmers with settlements in their destinations. Furthermore, extension agents do play a significant role in promoting livelihoods of rural households and contribute towards improved land access.

Keywords: Land access, livelihood strategy, rural households, South Africa

\section{INTRODUCTION}

\subsection{Background}

In South Africa, land access remains an emotive issue. Commentators and researchers attribute this to the history of land as a tool in the hands of settlers for creating economic and social dichotomies in the country rather than its contribution to gross national output (Bundy, 1987; Mabin, 1991; Adam, Cousins and Siyabulela, 2000 and Obi, 2011) among others. Hall and Cousins (2019) observed that, to the previously disadvantaged South African, land has both territorial significance as well as symbolic power that is intimately linked to their very identity

\footnotetext{
${ }^{1}$ Senior Lecturer/Researcher at the North West University: Agricultural Economics and Extension, P/Bag x 2046, Mmabatho, 2735. Tel. 018389 2786; E mail: mzuyanda1990@gmail.com, ORCID: 0000-0003-4446-0298

${ }^{2}$ Lecturer/Researcher at the North West University: Agricultural Economics and Extension, P/Bag x 2046, Mmabatho, 2735. Tel. 018389 2781; E mail: luvhengousapfa@ gmail.com, ORCID: 0000-0000-0000-0000

${ }^{3}$ H Khobai. Senior Lecturer/Researcher at the North West University: Economic Sciences, P/Bag x 2046, Mmabatho, 2735. Tel. 018389 2681; E mail: hlalefangk@gmail.com, ORCID: 0000-0002-9595-6691

${ }^{4}$ Professor, Department of Agricultural and Applied Economics, Rivers State University, PMB 5080, Port Harcourt, Nigeria ; E mail: iykeagbugba1@gmail.com
} 
as a people. This resulted from the bitterness about forced removals from their land, an action that was seen as a symbolic erasure of black identity and insights (Frost, 1998 and Obi, 2011). According to the Reconstruction and Development Programme document (RDP), land is a "basic need" of the people of South Africa (Kepe, 2016). However, agriculture, easily the main user of land worldwide and the sector accounts for more than $2.2 \%$ of South Africa's GDP, and roughly $8 \%$ of formal employment in the country (StatsSA, 2016). Of course, the relatively low share of agriculture in South Africa's GDP is more a reflection of the strength of the sector and the diversity of the economy as a whole. Ultimately, land must play a more important role in a transformation process where a significant segment of the population is unemployed and do not have the skills for meaningfully participating in other economic activities besides agriculture.

The current structure of the agricultural economy of South Africa implies that, land is the central productive resource and its ownership patterns are crucial where opportunities need to be equalized in the absence of alternative opportunities elsewhere in the economy (Bell, 1990; Van Zyl, Kirsten and Binswanger, 1996). This is especially true for the majority of previously disadvantaged population residing in the rural areas trying to participate in from a background of limited opportunities to develop skills to participate in the modern, monetized economy. For this segment of the population, it is inevitable for the dominant empowerment strategies to include agriculture.

Given the inevitable current and projected roles of agriculture in creating new employment opportunities for the previously disadvantaged population, and the central role of land in all this, how agricultural land is priced and distributed will continue to be important policy questions (Obi, 2006). The quantity of land bought and how profitably the new entrants into the farming business can operate are linked to how land is priced. Land prices would normally signal the market possibilities on the basis of which prospective investors would make a decision. In the South African context, policymakers are understandably uncomfortable at the prospect of high agricultural land prices since these would only worsen an already ugly picture of the extreme skewedness of land distribution throughout the country, especially as the majority of the population who buy land probably do so for political rather than for real agricultural production purposes. This view seems to be borne out by the large number of absentee land-owners among the beneficiaries under the land reform programme.

\subsection{Problem statement}

It has been 25 years since the enthronement of pluralistic democracy in South Africa and, efforts to redress socio-economic imbalance have been feverish although the disparities remain (Christian, Jiba \& Mdoda, 2020). There is an understandable sense of unease among policymakers over what could easily pass off as a market-assisted discrimination in a country where legislative fiat sustained the dispossession of a particular group of their land for nearly a century (Lyne and Darroch, 2003; Moyo, 2004 and Obi, 2006). Another major concern is that a projected GDP growth rate of $0.9 \%$ does not seem to make a dent on the current unemployment situation. For example, between 2008 and 2019, the official unemployment rate increased from about $22.43 \%$ to about $27 \%$ (StatsSA, 2016). This unemployment rate remains at the highest level since 2008. Surprisingly, South Africa has brought major policy adjustments particularly directed to smallholder farmer's upliftment. Notably is comprehensive support programme (CASP) which aims to empower black farmers under the Broad-based 
Black Economic Empowerment in Agriculture or AgriBEE as it is popularly known. However, there is no notably impact to rural livelihoods and household well-being. Ths the objective of the study is to analyze the impact of land access and livelihood strategies to well-being of households in Mnquma, Eastern Cape.

\section{CONCEPTUAL FRAMEWORK FOR LAND ACCESS, LIVELIHOOD STRATEGY AND WELL-BEING}

Within the context of market imperfections, the significance of tenacy arrangement for stimulating the growth in agriculture has long been acknowledged in the empirical and theoretical literature. For instance, Deininger et al. (2009) noted that in the presence of market imperfections where land transfers involve transaction cost, land rental markets are not efficient enough to gain socially optimal outcome.

In the presence of market imperfections, farming households face liquidity constraint in farm investment. Similarly, ownership security provides incentive for farmers to engage in longterm investment measures in many ways. Firstly, the secure tenancy improves credit availability of household to finance agricultural investments by using land title as collateral. As Feder and Feeny (1991) demonstrated that in the presence of credit constraints, ownership security results in greater investment by providing access to credit. Secondly, secure tenancy increases the possibilities for trade in recovering full value of the land by making it easier for farmers to liquidate their land in the case of exogenous shocks (Deininger and Jin, 2006).

\section{MATERIALS AND METHODS}

\subsection{Description of study area}

This study was conducted in Mnquma local municipality in the Eastern Cape's former Transkei area to gather data on income sources, demographic information and farming activities. Within Mnquma, there are three towns namely; Nqamakhwe, Centane and Butterworth. Hlobo, Ndabakazi, Kotane and Sihlabeni villages were randomly chosen. Data was collected between May to June 2015 where a sample of 100 respondents were randomly selected and interviewed. This sample was equally divided amongst the four villages as 25 respondents were selected from each village.

\subsection{Data collection}

The data collected for this study was collected between May and June 2015from household surveys. A semi-structured questionnaire was used to collect information from household heads using the local language, IsiXhosa, to enhance the understanding of the respondents. Data collected include ownership of land, household composition, assets, state and type of housing, toilet type and food availability. Focus group discussions were also used to supplement the information obtained from the household survey. The groups each consisted of 10 household heads, where information such as agricultural practices, well-being and processes of livelihood diversifications. Household heads over the age of 50 years, both females and males, were selected through the help of the headmen for the group discussion. Before conducting the survey, a workshop was given to enumerators and local field assistants. 


\subsection{Data analysis}

\subsubsection{Household characteristics, livelihood strategies and household well-being}

Analysis of data collected was done using STATA version 14 (StataCorp, College, TX, USA), whereby descriptive statistics such as averages, minimums, maximums, standard deviations, range, frequency counts and percentages were obtained to explain the household characteristics, well-being and livelihood strategies. The descriptive analysis has been widely used in similar studies such (McDermott, 2006; Perret, 2000), hence, it was deemed appropriate for this study given the nature of our data

\subsubsection{The impact of land access on household well-being}

To analyze the impact of land access and household demographic characteristics to household well-being, a multinomial logistic regression was used. The model is most suited because it has a single decision among two or more alternatives (Green, 2000). Assuming that $Y_{i}$ represents the choice taken, then with $\mathrm{J}$ disturbances being distributed identically and independently, the multinomial logit model will be represented as follows:

$\operatorname{Prob}\left(Y_{i}=j\right)=\frac{e^{\beta j x i}}{\sum_{k=0}^{J} e^{\beta k x i}}$ Where $\mathrm{j}=0,1 \ldots \ldots \mathrm{J}$

Equation (1) above represents a multinomial logistic regression model, where Prob (Y) indicates the probability of household to be well-off, $e$ is the natural $\log , \beta$ are coefficient and $\mathrm{k}$ is the intercepts.

\section{RESULTS AND DISCUSSION}

\subsection{Household demographic characteristics}

The demographic characteristics of the respondents assumed to have impact on household wellbeing are presented on Table 1 below. These characteristics included gender, age, marital status, level of education, household size and land size.

Table 1 shows that age is a crucial factor in diverse of the agricultural enterprises in the study area. The descriptive results in the table revealed the mean average age of participants to be 53 years, which basically indicate that the majority of household heads participate in the study are old people. The maximum age of respondents was 85 years and 56 percent were male. These findings suggest that agriculture in the rural smallholder farming is mostly done by older male people. These results are in line with smallholder Community Survey, which reported an average age range of 45-54 years (StatSA, 2016). Furthermore, Zantsi (2019) found similar results about land reform beneficiaries whom were elderly males. Furthermore, Male dominance in the study area may be attributed to loss of jobs through retrenchment policies, retirement and the high unemployment rate especially in the formal sector that requires more educated skilled labour. This is not far fall with the literature (Aliber \& Hart, 2009). However, in their study on socio-economic and profitability analysis of honey marketing, Agbugba et al. (2020) made a contrary observation by revealing that the dominance of elderly farmers in rural 
areas is due to lack of information literacy and infrastructure rather than retrenchments and unemployment in the secondary sector.

Table 1: Socio-demographic characteristics of farming households (Source: Field survey 2015)

\begin{tabular}{|c|c|c|c|c|c|}
\hline Characteristic & Description & \multicolumn{2}{|c|}{ Frequency } & \multicolumn{2}{|c|}{ Percentage $(\%)$} \\
\hline \multirow[t]{2}{*}{ Gender } & Male & \multicolumn{2}{|c|}{56} & \multicolumn{2}{|c|}{53.85} \\
\hline & Female & \multicolumn{2}{|l|}{48} & \multicolumn{2}{|l|}{46.15} \\
\hline \multirow{3}{*}{$\begin{array}{l}\text { Access to extension } \\
\text { services }\end{array}$} & Yes & \multicolumn{2}{|l|}{31} & \multicolumn{2}{|l|}{29.81} \\
\hline & No & \multicolumn{2}{|l|}{73} & \multicolumn{2}{|l|}{70.19} \\
\hline & & Mean & Std.Dev & Min & Max \\
\hline Age & Number(years) & 52.94 & 15.71 & 22 & 85 \\
\hline Level of education & Years spent at school & 2.89 & 1.21 & 1 & 5 \\
\hline Household size & Number of people in $\mathrm{HH}$ & 6.60 & 2.68 & 2 & 15 \\
\hline Land size & Land owned in $\mathrm{Ha}$ & 0.71 & 0.58 & 0.125 & 2.5 \\
\hline Farming experience & Years of involvement & 28.93 & 16.48 & 1 & 70 \\
\hline \multirow[t]{3}{*}{ Income } & Crop sales & 2377.74 & 2673.873 & 0 & 15400 \\
\hline & Livestock sale & 1579.9 & 940.98 & 0 & 6000 \\
\hline & $\begin{array}{l}\text { Crop + Livestock +off- } \\
\text { farm }\end{array}$ & 3957.6 & 3032.39 & 600 & 18400 \\
\hline
\end{tabular}

\subsubsection{Household size}

The mean average household size in Mnquma was 7 persons per household and ranged from 2 to 15 persons. Household size has a very important bearing with business, income and family livelihood. In essence, the use of family labour assisted in reduce the cost that would have been spent on hired labour.

\subsubsection{Level of education}

Education is a vital force to reckon with in effective farming household performance and could inform on how best a new technology is adopted. Data was collected from farmers interviewed on their level of education and the results presented in Table 1 above. The results revealed that, the average mean average for a number of years spent in school was 3 and ranging from 1 to 5 years.

\subsubsection{Farming experience}

Findings from Table 1 above indicated that the farming experience of interviewed individuals ranges from 1 to 70 years with an average of average is 29 years. The results also revealed that only $(7 \%)$ of farmers had 70 years of experience in farming. Most of experienced household heads, were able to get more productivity of crops by timely sowing of crops, avoid flood irrigation hence saving water and balanced use of fertilizers on account of their experience. 


\subsubsection{Land size}

The results indicate that every household had access to land either for crop or livestock production. Findings from Table 1 revealed that, the households in the study area own between 0.1 ha to $2.5 \mathrm{ha}$ of land with a standard deviation of $0.58 \mathrm{ha}$. These findings are in line with those reported by Perret et al. (2000) on a provincial level. The author claimed that $85 \%$ of rural households in the Eastern Cape have access to arable land, while $75 \%$ have access to shared grazing land

\subsubsection{Income sources}

Several authors (Barret et al., 2001; Shackleton \& Luckert, 2015) have discovered that it is rare to find households surviving only from one income source. Table 1 reports on the combination of livelihood strategies pursued by households in Mnquma. When grouping the main three contributing activities to household livelihoods, crop sales only, livestock sales, the combination of crop sales, livestock sales and off-farm income, it was found that most households depend on the combination of the three with a mean average of R4 000.00 a month.

\subsubsection{Access to extension services}

In South Africa, agricultural extension services are the most common forms of public sector support for knowledge diffusion and learning. The concept of extension services sector involves agricultural experts, who teach improved methods of farming in both livestock and cropping enterprises, demonstrate innovations, organise farmer meetings and markets. Smallholder farmers are the primary beneficiaries. The results in Table 1 indicate that of the surveyed farming households, $(70 \%)$ had no access to extension services.

\subsubsection{Livelihood strategies by gender}

This sub-section provides evidence as to whether or not the choices of livelihood strategy isinfluenced by gender. Accordingly, the findings provide a supporting evidence of statistically significant effect of livelihood strategy on gender shown on Table 2. After controlling other variables, it has been found that on average, about 1.92, 4.8 and 39.4 percent of participants who were male and had crop, livestock, crop+livestock+off-farm strategy.

Table 2: Livelihood strategy by gender of participants

\begin{tabular}{|c|c|c|c|c|c|c|c|c|}
\hline \multirow[t]{3}{*}{ Variable } & & \multicolumn{7}{|c|}{ Gender } \\
\hline & & \multicolumn{2}{|c|}{ Male } & \multicolumn{2}{|c|}{ Female } & \multicolumn{2}{|c|}{ Total } & \multirow[t]{2}{*}{ Chi2 } \\
\hline & & $\mathrm{n}$ & $\%$ & $\mathrm{n}$ & $\%$ & $\mathrm{~N}$ & $\%$ & \\
\hline \multirow{4}{*}{$\begin{array}{l}\text { Livelihood } \\
\text { strategy }\end{array}$} & Crop & 2 & 1.92 & 5 & 4.81 & 7 & 6.73 & \\
\hline & Livestock & 5 & 4.8 & 7 & 6.73 & 12 & 11.54 & 1.116 \\
\hline & Crop+Liv+Off-farm & 41 & 39.4 & 44 & 42.30 & 85 & 81.71 & \\
\hline & Total & 48 & 46.15 & 56 & 53.84 & 104 & 100 & \\
\hline
\end{tabular}

Source: Field survey 2015 


\subsubsection{Access to extension services by Well-being status}

This section provides evidence as to whether or not access to extension services had brought any improvement in household well-being. Accordingly, the findings provide a supporting evidence of statistically significant effect of livelihood strategy on household well-being shown on Table 3. After controlling all other variables that may have influence on household wellbeing, it has been found that on average, about 4.8, 1.9 and 23.1 percent of participants who using were not well-off, moderate and well-off status had access to extension services respectively. The findings also show that, on average about 18.3, 20.2 and 31.7 percent of the sample participants who were not well-off, moderate and well-off status did not receive extension services, respectively.

Table 3: Impact of extension service access on household well-being

\begin{tabular}{|c|c|c|c|c|c|c|c|c|c|c|}
\hline \multirow{3}{*}{\multicolumn{2}{|c|}{ Variable }} & \multicolumn{8}{|c|}{ Well-being status } & \\
\hline & & \multicolumn{2}{|c|}{ Not well-off } & \multicolumn{2}{|c|}{ Moderate } & \multicolumn{2}{|c|}{ Well-off } & \multicolumn{2}{|l|}{ Total } & Chi2 \\
\hline & & Numb & $\%$ & Numb & $\%$ & Numb & $\%$ & Num & $\%$ & \multirow{4}{*}{9.9} \\
\hline \multirow{3}{*}{$\begin{array}{l}\text { Access to } \\
\text { extension }\end{array}$} & Yes & 5 & 4.8 & 2 & 1.9 & 24 & 23.1 & 31 & 29.8 & \\
\hline & No & 19 & 18.3 & 21 & 20.2 & 33 & 31.7 & 73 & 70.2 & \\
\hline & Total & 24 & 23.1 & 23 & 22.1 & 57 & 54.8 & 104 & 100 & \\
\hline
\end{tabular}

Source: Field survey 2015

\subsubsection{Crop production}

Despite the fact that almost all the sampled respondents own or have access to arable land, very few were cultivating the fields and more were cultivating gardens. Most of the fields, except for Kotane, are not fenced and it has been a while. In terms of garden cultivation, a large proportion $(85 \%)$ of respondents cultivate gardens adjacent to their homestead. These results corroborate what the existing literature says in that rural households have not completely abandoned crop production; they have rather left field cultivation and focused on garden cultivation (Andrew \& Fox, 2004).

The results indicate that cabbage (99\%), maize $(95 \%)$ and potato $(94 \%)$ were the most produced crop in Mnquma. All the respondents who claim to be producing in their small gardens planted all the three crops in the previous production season. This is in line with what Christian et al. (2017) found Nqamakhwe and surrounding areas of Transkei. There are some households that produced carrots (49\%), tomato (34\%) and beetroot $(25 \%)$. 


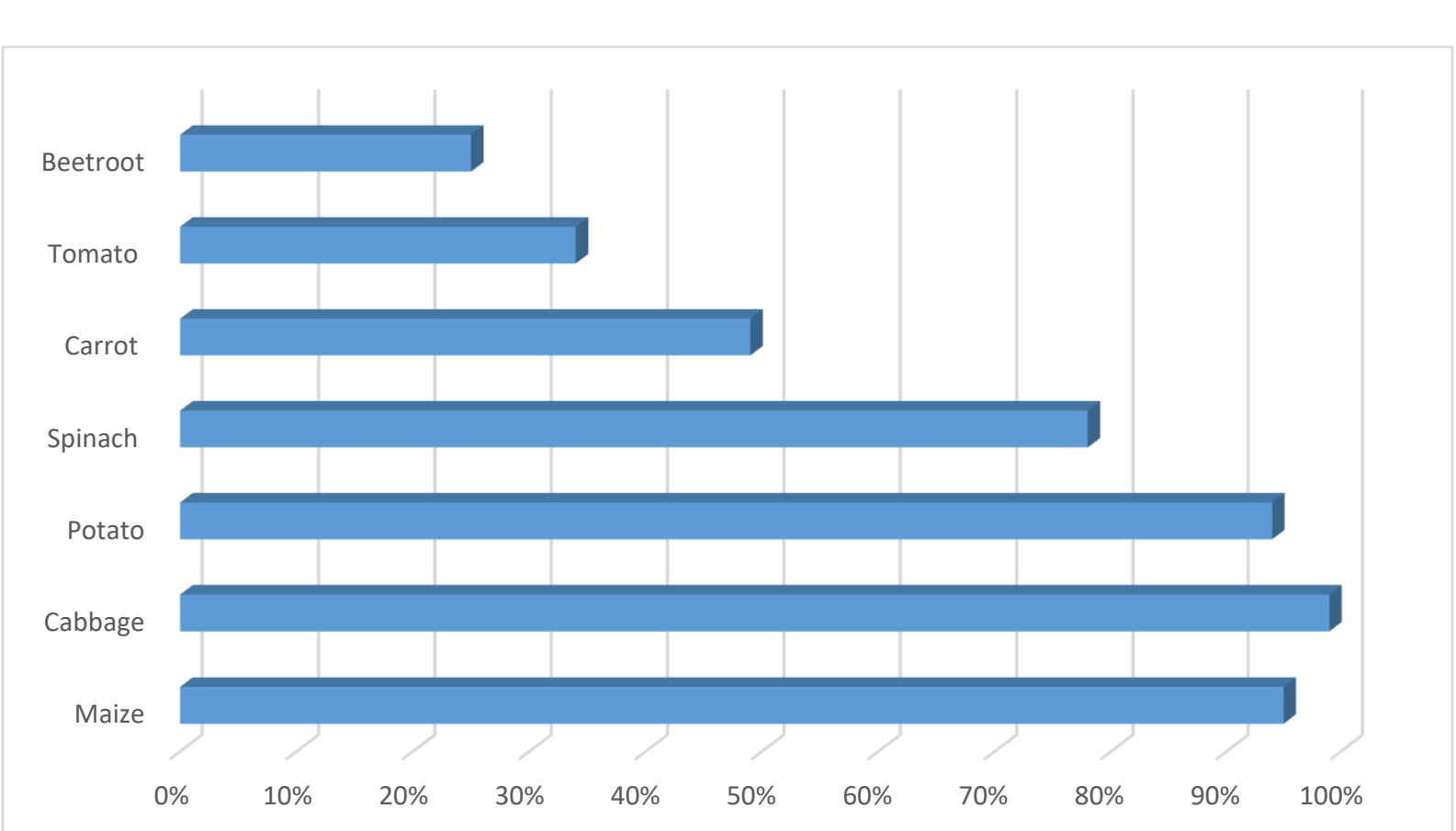

Figure 1: Crop production

Source: Authors computation

\subsubsection{Livestock production in Mnquma}

Results of the field survey revealed that majority of the farmers practice mixed farming with majority of farmers involved in livestock production. The main livestock kept by households in Mnquma include indigenous chicken $(79 \%)$ and cattle $(71 \%)$. The widespread farming of chickens may be due to their easy accessibility as they are relatively cheap and the lending is more common in chickens than in any other livestock types. Goat (57\%), sheep (56\%) and pigs (54\%) were the least kept animals in Mnquma. Most households indicated that fewer households own livestock now as compared to the olden days. Respondents who were practicing large-stock production (Cattle) also stated that the main reason for their involvement is the availability of pastures and they consider cattles as a form of wealth and security. There were however some households that did not own any of these livestock types. Following discussions during data collection, they pointed out that the cost of purchase, vaccines and diseases are the main reasons for not keeping such animals. In around 1996, the majority of farmers in the Eastern Cape were hard hit by "Umbendeni" (red-water disease) that resulted in a massive deaths of cattle's. The average household livestock holdings are presented in Figure 2. 


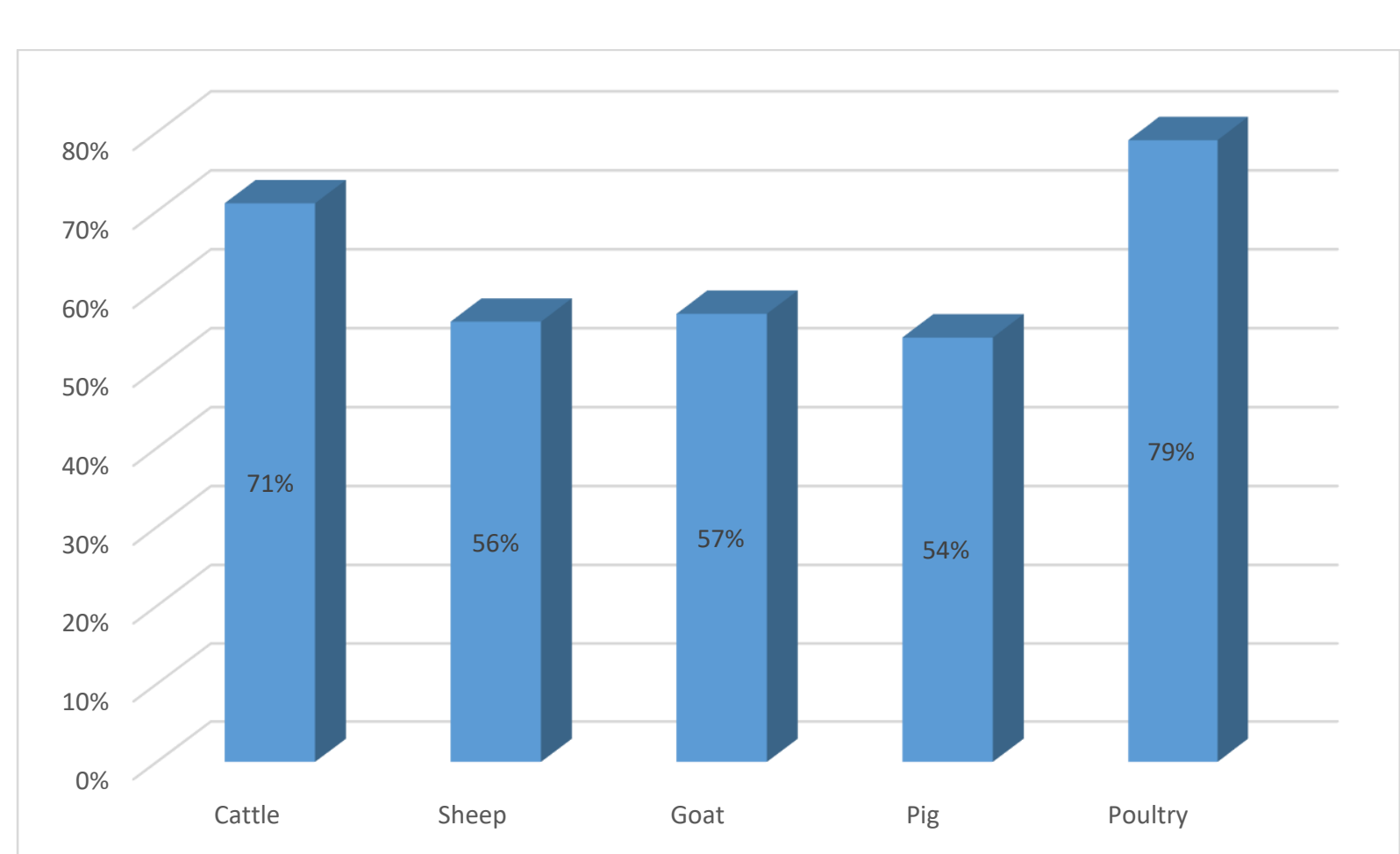

\section{Figure 2: Livestock production}

Source: Authors computation

\subsection{Livelihood strategies and household well-being}

This section provides evidence as to whether or not the choices of livelihood strategy had brought any improvement in household well-being. Accordingly, the findings provide a supporting evidence of statistically significant effect of livelihood strategy on household wellbeing shown on Table 4. After controlling other variables, it has been found that on average, about $0.96,3.85$ and 18.27 percent of participants who using crop farming, crop and livestock and crop plus livestock plus off farm strategies were not well-off respectively. The findings also show that, on average about 3.84, 1.92 and 51 percent of the sample participants who use crop only, crop and livestock, crop plus livestock plus off farm strategies were well-off, respectively.

Table 4: Impact of livelihood diversification on household well-being

\begin{tabular}{|c|c|c|c|c|c|c|c|c|c|c|}
\hline \multirow{3}{*}{\multicolumn{2}{|c|}{ Variable }} & \multicolumn{8}{|c|}{ Livelihood strategy } & \\
\hline & & \multicolumn{2}{|c|}{$\begin{array}{l}\text { Crop farming } \\
\text { only }\end{array}$} & \multicolumn{2}{|c|}{ Crop+Livestock } & \multicolumn{2}{|c|}{$\begin{array}{l}\text { Crop } \\
\text { livestock } \\
+ \text { non-farming }\end{array}$} & \multicolumn{2}{|l|}{ Total } & $\begin{array}{l}\text { Ch } \\
\text { i2 }\end{array}$ \\
\hline & & Numb & $\%$ & Numb & $\%$ & Numb & $\%$ & Num & $\%$ & \multirow{5}{*}{9.5} \\
\hline \multirow{4}{*}{$\begin{array}{l}\text { Well- } \\
\text { being } \\
\text { status }\end{array}$} & $\begin{array}{l}\text { Not well- } \\
\text { off }\end{array}$ & 1 & 0.96 & 4 & 3.85 & 19 & 18.27 & 24 & 23.08 & \\
\hline & Moderate & 2 & 1.92 & 6 & 5.77 & 15 & 14.42 & 23 & 22.12 & \\
\hline & Well-off & 4 & 3.84 & 2 & 1.92 & 51 & 51 & 57 & 54.8 & \\
\hline & Total & 7 & 6.73 & 12 & 11.54 & 85 & 81.73 & 104 & 100 & \\
\hline
\end{tabular}

Note: $* * *$ means significant at $1 \%$ level of significance

Source: Authors computation 


\subsection{The impact of land access on household well-being}

This section presents the result of the multinomial logistic regression model for the impact of land access and other factors affecting household well-being. According to Gujarati (1992), the coefficient values measured the expected change in the logit for a unit change in each independent variable, all other independent variables being equal. The sign of the coefficient shows the direction of the influence of the variable on the logit. It follows that a positive value indicates an increase in the likelihood that an access to land will change to the alternative option from the baseline group. Conversely, a negative value shows that it is less likely that access to land will consider the alternative (Gujarat, 1992; Pundo and Fraser, 2006).

The results in table 5 below show the estimated coefficients, Wald statistics and exponential betas of independent variables in the model. Table 4.3 shows that, the likelihood ratio $\left(\chi^{2}\right)$ value was $104.57(\mathrm{df}=32 ; \mathrm{p}=0.001)$ and this was significant at $1 \%$ level of probability. The pseudo $\mathrm{R}^{2}$ value of 0.540 shows the variation in the well-being status. Land size, income from crop sales, off-farm income and access to extension services had a positive effect on household well-being. Land did not have influence on household well-being as all the participants indicated that they had access to land.

Table 5: Multinomial logistic estimation for household well-being (Reference Category= Well-off)

\begin{tabular}{|c|c|c|c|c|c|c|}
\hline \multirow[b]{2}{*}{ Variable } & \multicolumn{3}{|l|}{ Well-off } & \multicolumn{3}{|l|}{ Not-well off } \\
\hline & Coefficient & Wald & $\begin{array}{l}\text { Exp. } \\
\text { (B) }\end{array}$ & Coefficient & Wald & $\operatorname{Exp}$. (B) \\
\hline Intercept & $\begin{array}{l}(1.444) \\
0.520\end{array}$ & 0.415 & & $\begin{array}{l}(-2.632) \\
0.380\end{array}$ & 0.770 & \\
\hline Age & $\begin{array}{l}(-0.003) \\
0.915\end{array}$ & 0.011 & 0.977 & $\begin{array}{l}(0.023) \\
0.650\end{array}$ & 0.206 & 1.023 \\
\hline Gender & $\begin{array}{l}(0.174) \\
0.798\end{array}$ & 0.65 & 1.190 & $\begin{array}{l}(-0.462) \\
0.673\end{array}$ & 0.179 & 0.630 \\
\hline Household size & $\begin{array}{l}(0.236) \\
0.193\end{array}$ & 2.236 & 1.697 & $\begin{array}{l}(-0.516) \\
0.135\end{array}$ & 2.236 & 0.597 \\
\hline Education level & $\begin{array}{l}(0.311) \\
0.531 \\
\end{array}$ & 0.393 & 1.365 & $\begin{array}{l}(-1.016) \\
0.238 \\
\end{array}$ & 1.393 & 0.362 \\
\hline Land size & $\begin{array}{l}(-0.286) \\
0.717 \\
\end{array}$ & 0.131 & 0.751 & $\begin{array}{l}(3.518) \\
0.019 * *\end{array}$ & 5.539 & 33.732 \\
\hline Income from crop sales & $\begin{array}{l}(-0.21) \\
0.026 * *\end{array}$ & 4.935 & 0.979 & $\begin{array}{l}(0.007) \\
0.038 * *\end{array}$ & 4.312 & 1.007 \\
\hline $\begin{array}{l}\text { Years of farming } \\
\text { experience }\end{array}$ & $\begin{array}{l}(0.064) \\
0.720\end{array}$ & 0.129 & 1.066 & $\begin{array}{l}(-0.241) \\
0.480\end{array}$ & 0.499 & 0.785 \\
\hline Land access & $\begin{array}{l}(-0.189) \\
0.839\end{array}$ & 0.041 & 0.828 & $\begin{array}{l}(0.087) \\
0.942\end{array}$ & 0.005 & 1.091 \\
\hline $\begin{array}{lll}\begin{array}{l}\text { Income from livestock } \\
\text { sales }\end{array} & & \\
\end{array}$ & $\begin{array}{l}(-0.361) \\
0.622\end{array}$ & 0.243 & 0.697 & $\begin{array}{l}(0.056) \\
0.961\end{array}$ & 0.002 & 1.057 \\
\hline Off-farm income & $\begin{array}{l}(-0.815) \\
0.328\end{array}$ & 0.956 & 0.443 & $\begin{array}{l}(-2.240) \\
0.065^{*}\end{array}$ & 3.402 & 0.106 \\
\hline
\end{tabular}




\begin{tabular}{|c|c|c|c|c|c|c|}
\hline Access to extension & $\begin{array}{l}(-0.009) \\
0.031 * *\end{array}$ & 0.000 & 0.991 & $\begin{array}{l}(-2.656) \\
0.062 *\end{array}$ & 3.474 & 0.070 \\
\hline Farm location & $\begin{array}{l}(-0.008) \\
0.739 \\
\end{array}$ & 0.111 & 0.992 & $\begin{array}{l}(0.051) \\
0.101 *\end{array}$ & 2.695 & 1.053 \\
\hline \multicolumn{7}{|c|}{ Model Summary } \\
\hline \multicolumn{7}{|c|}{$\begin{array}{l}\text { Note: } \\
\text { LR Chi: 53.558; -2 Log likelihood: } 104.571 ; \text { Pseudo } \mathbf{R}^{2}: .540 ; \mathbf{n}=104 ; \text { p-value }=0.001 \\
\text { Df=32 ***significant at } 1 \% \text { level, } * * \text { significant at } 5 \% \text { level, } * \text { significant at } 10 \% \text { level }\end{array}$} \\
\hline
\end{tabular}

Source: Authors computation

\section{CONCLUSION AND IMPLICATIONS FOR EXTENSION AGENTS}

\subsection{Conclusion}

This study aimed to assess the impact of land access, socio-demographic characteristics, and access to extension service on household well-being, to profile livelihood strategies of farmers, to find out the implications for the extension service. The study has successfully ascertained the factors that might positively and negatively impact on household well-being in Mnquma, Eastern Cape Province. The factors that positively impacted household well-being were found to be access to extension and income from crop sales.

\subsection{Implications for extension agents and recommendations}

Findings from this study confirm the ongoing decline contribution of agriculture in general and livestock farming in particular as main income source in rural households. This clearly implies that government agricultural extension advisory services should be strengthened and incorporate the goals of farming rural households. Caution against being biased towards encouraging and focusing solely on improving farming practices, but also encourage an effective combination of livelihood that would improve the welfare of farming households. More importantly, the Eastern Cape department of Agriculture and Rural Development should support distant farmers with settlements in their destinations.

\section{ACKNOWLEDGEMENTS}

The research was funded by the Water Research Commission while the first author's living expenses were covered under a DAAD-NRF bursary. The authors are grateful to these organisations and to the farmers, district agriculture office workers, and all those who participated in the data collection and analysis

\section{REFERENCES}

ADAM, M., COUSINS, B. AND SIYABULELA, M. 2000. "Land Tenure and Economic Development in Rural South Africa: Constraints and Opportunities" in B. Cousins (ed) At the Crossroads: Land and Agrarian Reform in South Africa into the $21^{\text {st }}$ Century, Braamfontein: PLAAS and NLC.

AFRICAN NATIONAL CONGRESS. 1994. "The Reconstruction and Development Programme", Pretoria, the African National Congress (ANC). 
AGBUGBA, I.K., AGBAGWA, S.K. AND DIABATE, Y. 2020. Socio-Economic and Profitability Analysis of Honey Marketing in Port Harcourt City Local Government Area of Rivers State, Nigeria, Journal of Economics and Sustainable Development, 11 (6), 1 8.

ANDREW, M. AND FOX, R.C. 2004. Undercultivation and intensification in the Transkei: A case study of historical change in the use of arable land in Nompa, Shixini. Dev. South. Afr., 21(4), 687-706.

ALIBER, M. AND HART, T.G.B. 2009. Should subsistence farming be supported as a strategy to address rural food insecurity? Agrekon, 48(4), 434-458.

BELL, C. 1990. "Reforming Property Rights in Land and Tenancy", The World Bank Research Observer, 5(2), 143-166.

BARRET, C.B., REARDON, T. AND WEBB, P., 2001. Nonfarm income diversification and household livelihood strategies in rural Africa: Concepts, dynamics, and policy implications. Food Policy, 26(4), 315-331.

BUNDY, C. 1987. "Land and Liberation, Popular Rural Protest, and the National Liberation Movement", in S. Marks and S. Trepido (eds.), The Politics of Race, Class and Nationalism in the Twentieth Century South Africa, Essex: Longman Group.

CHRISTIAN, M., JIBA, P. AND MDODA, L., 2020. Factors Influencing Rain-Fed Agricultural Land Abandonment in Mnquma and Mbashe Municipalities, Eastern Cape. International Journal of Recent Technology and Engineering. 9(2): 2277-3878.

CHRISTIAN, M. 2017. Impact Analysis of Smallholder Irrigation Schemes on THE choice of rural livelihood strategy and household food security and household food security in Eastern Cape Province, Unpublished PhD Thesis, Department of Agricultural Economics and Extension, University of Fort Hare, Alice, South Africa.

DEININGER, K. 1999. "Redistribution, Investment, and Human Capital Accumulation: The case of Agrarian Reform in the Philippines", Paper presented at the World Bank's Annual Conference on Development Economics, April 2000, Washington DC.

DORWARD, A., 2001. "Critical Linkages: Livelihoods, Markets and Institutions", Paper Presented at the Seminar on Supporting Institutions, Evolving Livelihoods, Bradford Centre for International Development, University of Bradford, 29-30 May, 2002.

FEDER, G. AND FEENY, D. 1991. "Land Tenure and Property Rights: Theory and Implications for Development Policy", The World Bank Economic Review, Vol. 5, No. 1, pp.135-153.

FROST, B. 1998. Struggling to Forgive - Nelson Mandela and South Africa's Search for Reconciliation, London, HarperCollins Publishers, pp. 173-206.

GREEN, W. H. 2000. Econometric analysis. $4^{\text {th }}$ edition. Pentice Hall, New Jersey.

GUJARATI, D. 1992. Essentials of Econometrics. New York: McGraw-Hill.

LYNE, M. \& AND DARROCH, M. 2003. "Land Redistribution in South Africa: past performance and future policy", in L. Nieuwoudt and J. Groenewald (eds.) The Challenges of Change: Agriculture, Land and the South African Economy, Natal, University of Natal Press.

MABIN, A. 1991. "The Impact of Apartheid on Rural Areas of South Africa," Antipote, 3346.

MCDERMOTT, L. 2006. Contrasting livelihoods in the upper and lower Garriep River basin: A study of livelihood changes and household development. Masters Thesis, Rhodes University. 
MACHETHE, C.L. 1955. “Approaches to Rural Development in the Third World: Lessons for South Africa", M.Sc. Dissertation submitted to the Department of Agricultural Economics, Michigan State University.

MANONA, C. 1999. De-agrarianisation and the urbanization of a rural economy: Agrarian patterns in Melani village in the Eastern Cape. ASC Working Paper. Rhodes University, South Africa.

MOYO, S. 2004. The Land Question, the State and Agrarian Transition: Contradictions of Neoliberal Reforms, Dakar, CODESRIA Greenbook Series Publication.

OBI, A. 2011. Institutional constraints to small farmer development in Southern Africa. The Netherlands: Wageningen Academic Publishers.

OBI A. 2006. - Trends in South African agricultural land prices, $\mathrm{PhD}$ thesis, University of The Free State, South Africa.

PERRET, S. 2000. Livelihood strategies in rural Transkei (Eastern Cape Province): How does wool production fit in? Working Paper 2002-20. University of Pretoria, South Africa.

PUNDO, M. O AND FRASER, G. C. G. 2006. Multinomial logit analysis of household cooking fuel choice in rural Kenya: The case of Kismu district. Agrekon, 45(1), 24-38.

SHACKLETON, S. AND LUCKERT, M. 2015. Changing livelihoods and landscapes in the rural Eastern Cape, South Africa: Past influences and future trajectories. Land Use Policy, 4(4), 1060-1089.

STATISTICS SOUTH AFRICA (StatsSA). 2016. Community household survey. Available from: www.statssa.gov.za.

VAN ZYL, J. AND BINSWANGER, H.P. 1996. "Market-assisted rural land reform: how will it work?", in J.van Zyl, J. Kirsten and H.P. Binswanger (eds), Agricultural Land Reform in South Africa, Cape Town, Oxford University Press.

VERSCHOOR, A.J. 2003. "Agricultural Development in the North-West Province of South Africa through the Application of Comprehensive Project Planning and Appraisal Methodologies", PhD Dissertation, Pretoria, Department of Agricultural Economics, Extension, and Rural Development, University of Pretoria.

ZANTSI, S. 2016. The influence of aspiration in changing livelihood strategies in rural households of Ndabakazi villages in the Eastern Cape. MSc Thesis, University of Fort Hare. 